Agro-Science Journal of Tropical Agriculture, Food, Environment and Extension Volume 21 Number 1 (January 2022) pp. $103-113$

ISSN 1119-7455

\title{
ENUMERATION OF CARBON AND NITROGEN CONTENTS OF WATER-STABLE AGGREGATES IN LAYERS OF TOPSOILS FROM CULTIVATED AND ADJACENT BUSH-FALLOW LOAMY SOILS
}

\author{
${ }^{* 1}$ Okebalama C.B., ${ }^{1}$ Igwe C.A. and ${ }^{2}$ Onunwa A.O. \\ ${ }^{1}$ Department of Soil Science, University of Nigeria, Nsukka, Nigeria \\ ${ }^{2}$ Department of Soil Science \& Land Resources Management, \\ Nnamdi Azikiwe University, Awka, Nigeria \\ *Corresponding author's email: chinyere.okebalama@unn.edu.ng; Tel: +234 803-538-7310
}

\begin{abstract}
Soil organic carbon (SOC) and total soil nitrogen (TSN) dynamics have both pedological and agronomic basis. Knowledge of their retention within aggregate hierarchies of varying soil textures as influenced by land use change is limited. The capacity of loam (L), clay loam (CL), sandy loam (SL) and sandy clay loam (SCL) soils to retain SOC and TSN in water-stable aggregate (WSA) at 10-cm intervals of 0-30 cm topsoil depths under cultivated and bushfallow/uncultivated systems was investigated. The soils showed high dispersion ratio and great variations in aggregate silt and clay indices $(C L>L>S C L>S L)$ under both land uses. Across soil depths, the uncultivated $C L, S L$ and $S C L$ soils had moderate to high $>2.00 \mathrm{~mm}$ WSA whose reduction due to cultivation impact was more pronounced in SL than in CL soil. Across soil depths and land uses, SOC content seemed higher in the macro- $(>0.50 \mathrm{~mm})$ than in the micro- $(<0.50 \mathrm{~mm})$ aggregates of all the soils while the reverse marked aggregate TSN content in almost all the soils. Cultivation mostly reduced macro-aggregate-associated SOC and TSN in $L>C L>S L$ and in $L>S L>C L>S C L$ soils, respectively. However, cultivation showed no reduction influence on micro-aggregate-associated SOC of all the soils. Cultivation-related reduction in micro-aggregate-associated TSN was more pronounced in the generally more 'clayey' $C L$ and SCL than the $L$ and $S L$ soils. So, the potential of bush-fallowing to enhance micro-aggregateassociated TSN storage and stabilization against adverse influence of cultivation depends on soil texture.
\end{abstract}

Key words: uncultivated soil, macro- and micro- aggregates, land use

\section{INTRODUCTION}

Soil organic carbon (SOC) and total soil nitrogen (TSN) are dynamic soil components that vary widely among soil types and land uses. This is so because organic carbon $(\mathrm{C})$ and nitrogen $(\mathrm{N})$ contents in cropland are strongly influenced by the quantity of $\mathrm{C}$ inputs, cropping intensity, soil and crop management practices (Rahman, 2013). Intensive cultivation of agricultural land contributes enormously to reduced SOC and TSN contents (Adesodun et al., 2007; Rahman, 2010) but fallow management system is reported to promote soil aggregate stability and thus stabilize aggregate SOC and TSN (Mtali-Chafadza et al., 2020). As important determinants of soil quality, SOC and TSN need to be conserved, and their conservation is essential to longterm sequestration of $\mathrm{C}$ and $\mathrm{N}$, and overall soil productivity. Increased SOC content improves soil structure and sustainability and enhances crop yield and productivity. However, SOC depletion has been associated with reduced soil aggregation and structural stability with attendant susceptibility to accelerated erosion in most tropical soils (Lal, 1991; 2019; BlancoCanqui and Benjamin, 2013; Liu et al., 2019)
Bush fallow has traditionally been recognized as an efficient, balanced and sustainable agricultural system for improving soil organic matter (SOM), soil productivity and fertility restoration in the tropics (Ramakrishnan, 1984; Schlecht and Buerkert, 2004; Ayoola and Adeniyan, 2006; Nhantumbo et al., 2009). Long fallow period of 5-8 years often promotes SOM and build-up of plant macro-nutrients in the soil (Salako et al., 1999). However, due to increasing population, economic changes and land fragmentation challenges, the length of fallow periods in producing fields has shortened to 4-5 years (Ramakrishnan, 1984; Ogban et al., 2004). The importance of fallow in agricultural sustainability relates to changes in soil physiochemical properties as influenced by fallow systems (bush fallow, forest fallow, improved fallow, bare fallow, etc), fallow duration (short, medium and long terms), soil types and agro ecological regions. Salako et al. (1999) reported that 1-3 years' fallow periods substantially enhanced soils aggregate stability irrespective of the fallow system. Conversely, MtaliChafadza et al. (2020) found no difference in soil nutrients accumulation with different fallow periods. 
Unlike fallow system, cultivation has been associated with deterioration in soil aggregate structure due to soil disturbances that destroy aggregates, expose encapsulated SOC to microbial processes and increase its vulnerability to decomposition and erosion (Adesodun et al., 2007; Lal, 2019). Hence, cultivation leads to reduction in amount and stability of macro-aggregates but not micro-aggregates (Tisdall and Oades, 1982). Soil susceptibility to structural degradation increased with years of cultivation (Shepherd et al., 2001). Differences in preferential accumulation of SOC and TSN in aggregate fractions also vary under different land use systems (Shrestha et al., 2007; Liu et al., 2019). Adesodun et al. (2007) found higher aggregate SOC and TSN in large macro-aggregates $(4.76-2.0 \mathrm{~mm})$ under uncultivated soils, and in micro-aggregate $(<0.25 \mathrm{~mm})$ under cultivated soils. The influence of cultivation on SOC loss as affected by soil texture and soil depth has also been reported. Okebalama et al. (2017) found that loss of C pool in different soil textures was higher at $0-10 \mathrm{~cm}$ top surface layer than the lower soil depths (10-20 and 20$30 \mathrm{~cm}$ ). Also, Campbell and Souster (1982) reported high losses of C on sandy soils, while Saggar et al. (2001) found that percentage C losses from silt loam soil was 1.5 times higher than from silty clay loam.

Most often, SOC and TSN components, as well as soil structure, are often altered through soil management practices (Bronick and Lal, 2005). Conversion of fallow land to agricultural cultivated land has been shown to alter soil structural and chemical characteristics (Salako et al., 1999; Adesodun et al., 2007). Due to the dynamic nature of SOC and TSN in soil aggregates, precise evaluation of the effect of bush-fallow and cultivation on soil aggregate stability in relation to aggregate SOC and TSN is imperative for maintaining soil physical and chemical fertility in agroecosystems. Such assessment could also be useful for developing long-term and process-based strategies for improving and sustaining biodiversity in managed ecosystems. Information from the study can help farmers and land users to manage soils in a sustainable manner.

Although aggregate $\mathrm{C}$ and $\mathrm{N}$ contents in relation to aggregate stability under different management systems have been assessed (Puget et al., 2000; Adesodun et al., 2007; Onweremadu et al., 2007, Shrestha et al., 2007), there is limited research on the capability of different soil textures to retain $\mathrm{C}$ and $\mathrm{N}$ in water stable aggregates (WSA) following cultivation of erosive susceptible soils of the humid tropics. The extent to which short fallow (4-5 years) could influence $\mathrm{C}$ and $\mathrm{N}$ stabilization in aggregate hierarchies of varying soil textures against adverse environmental processes associated with cultivation is still unknown. Our study assessed soil aggregate stability in water, as well as the storage and distribution of aggregate-associated SOC and TSN in four different soil textural types at $10 \mathrm{~cm}$ segmental layer of the topsoil $(0-30 \mathrm{~cm})$ under cultivated and uncultivated land uses. Recognizing the important role of finer soil particles in soil aggregation, the study therefore hypothesized that change in landuse would induce greater macro-aggregate $(>0.50 \mathrm{~mm})$ associated SOC and TSN losses in sand dominated than in clay or silt dominated textured soils.

\section{MATERIALS AND METHODS}

\section{The Study Locations and Environment}

Soils used in this study were collected from locations at Awgu, Okigwe and Nsukka I and II, in Southeastern Nigeria. Awgu is located at $5^{\circ} 43^{\prime} \mathrm{N}$ and $7^{\circ} 21^{\prime} \mathrm{E}$; Okigwe at $5^{\circ} 28^{\prime} \mathrm{N}$ and $7^{\circ} 32^{\prime} \mathrm{E}$, and Nsukka I and II between $6^{\circ} 52^{\prime} \mathrm{N}$ and $6^{\circ} 41^{\prime} \mathrm{N}$ and $7^{\circ} 24^{\prime} \mathrm{E}$ and $7^{\circ} 17^{\prime} \mathrm{E}$. Figure 1 shows the relative positions of the study areas in Southeastern Nigeria. Climate of the study area is humid tropical with average annual bimodal rainfall of about $1700 \mathrm{~mm}$ and annual temperature of $26^{\circ} \mathrm{C}$ (Climate-Data, 2021). The underlying geology of Nsukka is mainly Sandstone, whereas Awgu and Okigwe are of Shale origin (Jungerius, 1964; Orajaka, 1975; Onyewuchi and Ugwu, 2017). Nsukka and Okigwe are of hilly terrain while Awgu is more of a flat land. Detailed description of individual locations, soil classification, and land-use history of the fields is presented (Table 1).

Soil samples were collected from these locations having different soil textures to ensure variability of these soil parameters. From each location, soils were sampled from two different land uses (cultivated and adjacent bush-fallow/uncultivated farmlands) at three successive depths $(0-10,10-20$ and $20-30 \mathrm{~cm})$, giving six samples per location. Soils were sampled up to $30 \mathrm{~cm}$ depth because tillage practice in the study area did not exceed $30 \mathrm{~cm}$ soil depth. The selection of cultivated and uncultivated farmlands was aimed at ensuring variability in aggregate stability of the soils since we assumed that soil physiochemical properties were altered upon change in land use. Generally, the farmlands are indiscriminately established by local farmers at no definite pattern.

\section{Soil Analysis}

The collected soil samples were air-dried and divided into two portions. A portion sieved with $4.75 \mathrm{~mm}$ mesh was used for aggregate size separation while the other $2.00 \mathrm{~mm}$ sieved portion was used for soil physiochemical determinations. Aggregate size separation was performed by wet sieving (Elliot, 1986). Using a nest of four sieves $(2.00,1.00,0.50$ and $0.25-\mathrm{mm}$ mesh), a $100 \mathrm{~g}$ of the $<$ $4.75 \mathrm{~mm}$ soil sample was weighed into the topmost sieve and submerged in water at room temperature for $5 \mathrm{~min}$. The sieves were vertically oscillated 50 times in a water oscillation machine in about $2 \mathrm{~min}$. Thereafter, the WSA retained on each sieve $(>2.00,1.00-2.00,0.50-1.00$, $0.25-0.50$, and $<0.25 \mathrm{~mm}$ ) were oven-dried at $40^{\circ} \mathrm{C}$, and

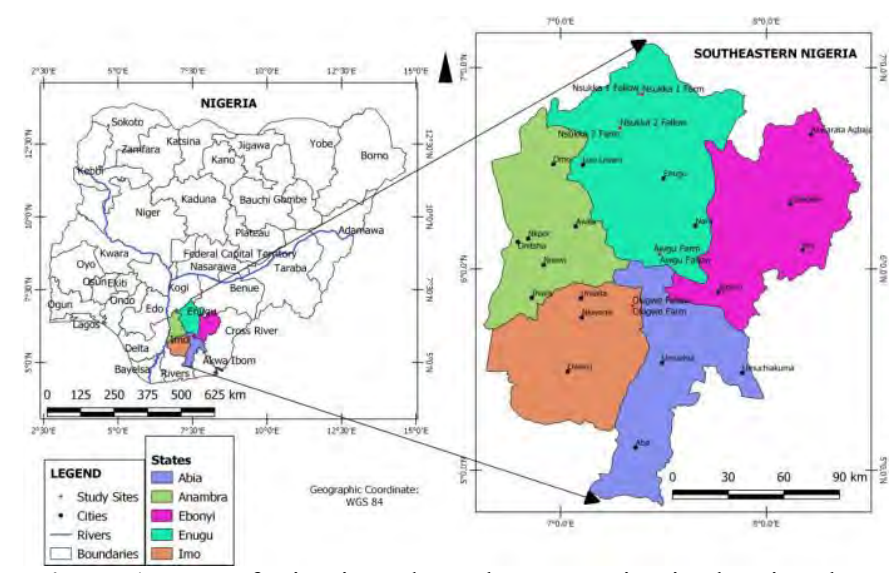

Figure 1: Map of Nigeria and Southeastern Nigeria showing the study locations 
Table 1: Study sites description, soil classification and land-use history

\begin{tabular}{|c|c|c|c|}
\hline Location/soil classification & Land use & Cropping system and Predominant vegetation & Tillage practice/land use history \\
\hline \multirow[t]{2}{*}{$\begin{array}{l}\text { Awgu } \\
\text { (Typic Paleudult) }\end{array}$} & Cultivated farmland & Cassava monocropping without soil amendment & $\begin{array}{l}\text { Field was manually tilled with } \\
\text { hoes after } 5 \text { years bush-fallow }\end{array}$ \\
\hline & Uncultivated field & Plantain, banana, mango and oil palm trees & Five years bush-fallow field \\
\hline \multirow[t]{2}{*}{$\begin{array}{l}\text { Okigwe } \\
\text { (Typic Hapludult) }\end{array}$} & Cultivated farmland & $\begin{array}{l}\text { Cassava, yam and maize intercrop without fertilizer application; } \\
\text { Mulching with harvested maize stover and weed residues }\end{array}$ & $\begin{array}{l}\text { Field was manually tilled with } \\
\text { hoes after a 5-year bush-fallow }\end{array}$ \\
\hline & Uncultivated field & $\begin{array}{l}\text { Oil palm, orange and oil bean trees, including Mimosa pudica, } \\
\text { Panicum maximum, and Pennisetum purpureum grasses }\end{array}$ & $\begin{array}{l}\text { Five-year bush-fallow } \\
\text { agricultural field }\end{array}$ \\
\hline \multirow[t]{2}{*}{$\begin{array}{l}\text { Nsukka I } \\
\text { (Typic Kandiustult), } \\
\text { (Nkpologu series) }\end{array}$} & Cultivated farmland & $\begin{array}{l}\text { Under a 3-year continuous cultivation of sorghum - soybean } \\
\text { intercrop with application of swine and poultry droppings at } \\
15 \mathrm{Mg} \mathrm{ha}^{-1} \text { and } 90 \mathrm{~kg} \mathrm{ha}^{-1} \mathrm{NPK} \text { 15:15:15 fertilizer }\end{array}$ & $\begin{array}{l}\text { Field was conventionally tilled } \\
\text { for three consecutive years after } \\
\text { a 4-year bush-fallow }\end{array}$ \\
\hline & Uncultivated field & $\begin{array}{l}\text { Scattered gmelina trees and shrubs, Panicum maximum, } \\
\text { Cyperus esculentus, Spermacoce verticillata, and } \\
\text { Cynodon nlemfuensis grasses }\end{array}$ & $\begin{array}{l}\text { Research field under a 4- year } \\
\text { bush-fallow }\end{array}$ \\
\hline \multirow{2}{*}{$\begin{array}{l}\text { Nsukka II } \\
\text { (Typic Paleustult), } \\
\text { (Uvuru series) }\end{array}$} & Cultivated farmland & $\begin{array}{l}\text { Cassava, maize, yam and fluted pumpkin mixed-cropping } \\
\text { with application of poultry manure }\end{array}$ & $\begin{array}{l}\text { Field was conventionally-ridged } \\
\text { across the slope }\end{array}$ \\
\hline & Uncultivated field & $\begin{array}{l}\text { Scattered plantain, oil palm, gmelina trees. Mimosa pudica, } \\
\text { Andropogon gayanus, Oldenlandia corymbosa, Guterbergia spp. }\end{array}$ & $\begin{array}{l}\text { Four years bush-fallow } \\
\text { agricultural land }\end{array}$ \\
\hline
\end{tabular}

Adapted from Okebalama et al. (2017)

then weighed and used to determine aggregate SOC and TSN. The mass of aggregates $>0.25 \mathrm{~mm}$ was calculated by subtracting the sum of the oven-dried weights of materials retained on each sieve from the air-dried weight of the original sample. The proportion of each aggregate class in the total sample weight was thus computed as the ratio of its oven-dry weight (uncorrected for sand) to the weight of the material $(100 \mathrm{~g})$ before sieving.

Particle size analysis of $<2.00 \mathrm{~mm}$ soil fractions was done by hydrometer method (Gee and Bauder, 1986), using calgon as dispersant. Deionized water alone was used to determine water dispersible clay (WDC) and water dispersible silt (WDSi). The micro-aggregate stability indices of the soils including clay dispersion index (CDI), dispersion ratio (DR), aggregated silt and clay (ASC) and clay flocculation index (CFI) were calculated as follows (Igwe et al., 1999):

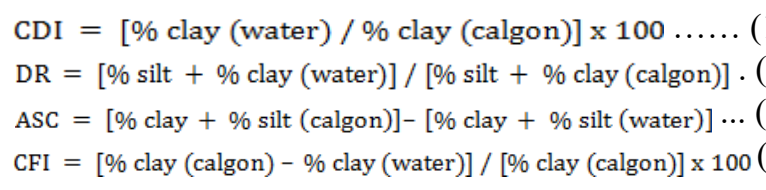

Soil $\mathrm{pH}$ was measured in $1: 2.5$ soil to water suspensions using a $\mathrm{pH}$ meter. The SOC concentration in the whole soil $(<2.00 \mathrm{~mm})$ and in the various WSA fractions were determined by Walkley and Black wet oxidation method (Nelson and Sommers, 1982), and SOM computed by multiplying the OC by the Van Bemmelen factor of 1.724. The macro-Kjeldahl digestion method using $\mathrm{CuSO}_{4}$ and $\mathrm{Na}_{2} \mathrm{SO}_{4}$ catalyst mixture as described by Bremner and Mulvaney (1982) was used for the determination of total $\mathrm{N}$ concentration in WSA fractions. Cation exchange capacity (CEC) was determined by the $\mathrm{NH}_{4} \mathrm{OAC} \mathrm{pH} 7$ method (Thomas, 1982).

\section{Statistical Analysis}

Data were descriptively analyzed using Microsoft Excel 2016 to estimate population mean and percent coefficient of variation. Line graphs and column charts were used to show relationships and distributions of measured parameters amongst the soil textures and across soil depths and land uses.

\section{RESULTS}

\section{Physiochemical Properties of the Soils}

The particle size distribution of soils as presented in Table 2 show wide distribution in the content of soil separates; particularly the silt content, which ranged from 3 to $49 \%$ with a CV of $77 \%$ across soil depths and land uses. Percent silt content in Awgu was two-times more than that in Okigwe, and four-times more than that in Nsukka I and II. Also, percent silt content declined with soil depth in Awgu and Okigwe cultivated soils while percent clay content tended to increase with soil depth in almost all the locations and under both land uses. Accordingly, Okigwe soil had moderate clay and sand particles while Nsukka I and II soils had more of sand than clay and silt particles. Across land uses, the textural classes which also varied slightly with soil depth in all the locations except at Nsukka II, mainly included clay (C), loam (L), clay loam (CL), sandy loam (SL) and sandy clay loam (SCL) at $0-30 \mathrm{~cm}$.

Across land uses and soil depths, the microaggregate stability indices of the soils (Table 3) show that the clay dispersion index (CDI) was between 25.16 and 63.59 , with a mean of 44.08 and a CV of $28 \%$. However, the degree of variation in CDI was slightly more under the cultivated $(30.78 \%)$ than the uncultivated $(25.30 \%)$ land use. As such, highest CDI was obtained in SCL $(46.28 \%)$ and CL $(53.72 \%)$ soils under cultivated and uncultivated land uses, respectively. Across land uses, CDI was maximal at $0-10 \mathrm{~cm}$ depth in $\mathrm{L}$ and CL soils, but minimal at the same depth in SCL soil. Except in uncultivated CL soil showing decreased CDI values with soil depth, the CDI followed no distinct trend with soil depth for the other soils in both land uses. Dispersion ratio (DR) values averaged 0.71 with a low CV of $13 \%$; aggregated silt and clay (ASC) and water dispersible silt (WDSi) values show wide variations with an average of $12.72(\mathrm{CV}=51 \%)$ and $19.17(\mathrm{CV}=56 \%)$, respectively. As such, maximum ASC and WDSi values were obtained in $\mathrm{CL}$ and $\mathrm{L}$ textured soils, respectively. High CV (33\%) was observed with WDC, which ranged from 6.48 to 20.48 ; wherein the maximum value of between 10.48 and 20.48 was obtained in CL soils across soil depths and land uses. 
Table 2: Particle size distribution and textural classification of the soils under cultivated and uncultivated land uses

\begin{tabular}{|c|c|c|c|c|c|}
\hline Location & $\begin{array}{l}\text { Soil depth } \\
\text { (cm) }\end{array}$ & $\begin{array}{c}\% \\
\text { Clay }\end{array}$ & $\begin{array}{c}\% \\
\text { Silt } \\
\end{array}$ & $\begin{array}{c}\% \\
\text { Sand }\end{array}$ & Textural class \\
\hline & \multicolumn{5}{|c|}{ Cultivated } \\
\hline \multirow[t]{4}{*}{ Awgu } & $0-10$ & 17 & 49 & 34 & Loam \\
\hline & $10-20$ & 27 & 39 & 34 & Loam \\
\hline & $20-30$ & 31 & 23 & 46 & Sandy Clay Loam \\
\hline & Mean & 25 & 37 & 38 & \\
\hline \multirow[t]{4}{*}{ Okigw } & $0-10$ & 27 & 23 & 50 & Sandy Clay Loam \\
\hline & $10-20$ & 43 & 15 & 42 & Clay \\
\hline & $20-30$ & 47 & 9 & 44 & Clay \\
\hline & Mean & 39 & 16 & 45 & \\
\hline \multirow[t]{4}{*}{ Nsukka } & $0-10$ & 16 & 9 & 76 & Sandy Loam \\
\hline & $10-20$ & 22 & 7 & 72 & Sandy Clay Loam \\
\hline & $20-30$ & 22 & 7 & 72 & Sandy Clay Loam \\
\hline & Mean & 20 & 8 & 73 & \\
\hline \multirow[t]{6}{*}{ Nsukka } & $0-10$ & 26 & 7 & 68 & Sandy Clay Loam \\
\hline & $10-20$ & 26 & 9 & 66 & Sandy Clay Loam \\
\hline & $20-30$ & 30 & 5 & 66 & Sandy Clay Loam \\
\hline & Mean & 27 & 7 & 67 & \\
\hline & $\% \mathrm{CV}$ & 34 & 86 & 28 & \\
\hline & \multicolumn{5}{|c|}{ Uncultivated } \\
\hline \multirow[t]{4}{*}{ Awgu } & $0-10$ & 27 & 39 & 34 & Loam \\
\hline & $10-20$ & 31 & 25 & 44 & Clay Loam \\
\hline & $20-30$ & 27 & 29 & 44 & Loam \\
\hline & Mean & 28 & 31 & 41 & \\
\hline \multirow[t]{4}{*}{ Okigw } & $0-10$ & 17 & 25 & 58 & Sandy Loam \\
\hline & $10-20$ & 31 & 25 & 44 & Clay Loam \\
\hline & $20-30$ & 43 & 13 & 44 & Clay \\
\hline & Mean & 30 & 21 & 49 & \\
\hline \multirow[t]{4}{*}{ Nsukka } & $0-10$ & 14 & 11 & 76 & Sandy Loam \\
\hline & $10-20$ & 21 & 8 & 72 & Sandy Clay Loam \\
\hline & $20-30$ & 25 & 10 & 66 & Sandy Clay Loam \\
\hline & Mean & 20 & 10 & 71 & \\
\hline \multirow[t]{6}{*}{ Nsukka } & $0-10$ & 26 & 3 & 72 & Sandy Clay Loam \\
\hline & $10-20$ & 28 & 7 & 66 & Sandy Clay Loam \\
\hline & $20-30$ & 22 & 7 & 72 & Sandy Clay Loam \\
\hline & Mean & 25 & 6 & 70 & \\
\hline & $\% \mathrm{CV}$ & 28 & 71 & 25 & \\
\hline & Grand $\% \mathrm{CV}$ & 31 & 77 & 26 & \\
\hline
\end{tabular}

The soil $\mathrm{pH}$ ranged from 4.5 (strongly acidic) to 5.9 (moderately acid) across the soil textures and land uses, with a mean of 5.2 and $\mathrm{CV}$ of $6 \%$ (Figure 2). A large variation (42\%) in SOM content was observed across soil depths and land uses, with maximum (4.22\%) and minimum $(0.67 \%)$ values in the $\mathrm{CL}$ and SL soils, respectively (Figure 3). Except in L soil, SOM decreased with soil depth in all the uncultivated soils and in cultivated CL and SCL soils. The CEC of soils ranged from 7.2 to $27.60 \mathrm{cmol}_{\mathrm{c}} \mathrm{kg}^{-1}$ with a CV of $44 \%$ across soil depths and land uses (Figure 4). However, the CEC mean values under the cultivated and uncultivated land uses was $21.20 \mathrm{cmol}_{\mathrm{c}} \mathrm{kg}^{-1}$ with a $\mathrm{CV}$ of $18 \%$, and 9.50 $\mathrm{cmol}_{\mathrm{c}} \mathrm{kg}^{-1}$ with a CV of $20 \%$, respectively.

\section{Water-Stable Aggregate Fractions of the Soil Textural Types}

Results of Table 4 show great variation $(\mathrm{CV}>54 \%)$ in the proportions of WSA amongst soils textures, across soil depths and land uses. Pooled over soil depths, the proportion of $>2.00 \mathrm{~mm}$ WSA in SCL, CL, L and SL soils was $79.25 \%, 53.04 \%, 20.71 \%$ and $18.89 \%$, respectively, in the cultivated land; and 78.85, 66.07, 6.77 and $49.38 \%$, respectively, under the uncultivated land use. The $>2.00 \mathrm{~mm}$ WSA of the soil textural types decreased with increasing soil depth in both land uses; except in the uncultivated L and SCL soils with no definite trend. More so, reduced proportions of $>2.00 \mathrm{~mm}$ WSA with concomitant increase in almost $<2.00 \mathrm{~mm}$ WSA fractions at $0-30 \mathrm{~cm}$ depth was observed in the cultivated soils of CL and SL than their uncultivated counterpart.

\section{Soil Organic Carbon Concentrations in Water-Stable Aggregates}

With $\mathrm{CV}>30 \%$, the aggregate SOC of the soils as presented in Figure 5 showed ranges of $0.38-2.01 \%$, $0.57-1.74 \%, 0.37-1.14 \%$, and $0.53-1.48 \%$ in the L, CL, SL and SCL soils, respectively, across WSA fractions, soil depths and land uses. The SOC concentrations in almost all of the WSA fractions decreased with increasing soil depth in the cultivated and uncultivated $\mathrm{CL}$ soils and in the uncultivated $\mathrm{L}$ soil. Maximum concentration of SOC at $0-10 \mathrm{~cm}$ across WSA fractions was observed in all the soils, except in the cultivated $\mathrm{L}$ and SCL soils. The aggregate SOC distribution in SCL soil was greater at $10-20>0-10>20-30 \mathrm{~cm}$ soil depth. Pooled over soil depths, all the soils textural types generally show elevated SOC concentrations in macro-aggregates $(>0.50 \mathrm{~mm})$ than in micro-aggregates $(<0.50 \mathrm{~mm})$. However, macro-aggregate associated SOC $(>0.50 \mathrm{~mm}$ WSA) were more in the uncultivated than the cultivated soils of L and CL textures, whereas the reverse was obtained with SCL soil. The macroaggregate-associated SOC concentrations in SL soil were comparable under both land uses; except in the 1.00-2.00 mm WSA fraction which contained reduced SOC under the cultivated than the uncultivated land use. Further, the micro-aggregates associated SOC concentration in the L, CL and SL soils were comparable under both land uses, but increased more in the cultivated than in the uncultivated SCL soil.

Table 3: Micro-aggregate stability indices of the soils under cultivated and uncultivated land uses

\begin{tabular}{|c|c|c|c|c|c|c|c|}
\hline \multicolumn{2}{|c|}{$\begin{array}{l}\text { Soil texture/ } \\
\text { Depth }(\mathrm{cm})\end{array}$} & CDI & \multicolumn{3}{|c|}{$\%$} & $\begin{array}{c}\% \\
\text { WDC } \\
\end{array}$ & \multirow[t]{2}{*}{$\begin{array}{c}\% \\
\text { WDSi } \\
\end{array}$} \\
\hline & & \multicolumn{5}{|c|}{ Cultivated } & \\
\hline \multirow[t]{3}{*}{ Loam } & $0-10$ & 51.46 & 0.76 & 16.00 & 48.54 & 8.48 & 41.28 \\
\hline & $10-20$ & 32.02 & 0.76 & 16.00 & 67.98 & 8.48 & 41.28 \\
\hline & $20-30$ & 47.51 & 0.78 & 12.00 & 52.49 & 14.48 & 27.28 \\
\hline Clay & $0-10$ & 77.34 & 0.60 & 20.00 & 22.66 & 20.48 & 9.28 \\
\hline \multirow[t]{2}{*}{ Loam } & $10-20$ & 29.38 & 0.52 & 28.00 & 70.62 & 12.48 & 17.28 \\
\hline & $20-30$ & 26.85 & 0.57 & 24.00 & 73.15 & 12.48 & 19.28 \\
\hline Sandy & $0-10$ & 41.12 & 0.70 & 7.28 & 58.88 & 6.48 & 10.56 \\
\hline \multirow[t]{2}{*}{ Loam } & $10-20$ & 48.16 & 0.74 & 7.28 & 51.84 & 10.48 & 10.56 \\
\hline & $20-30$ & 38 & 0.74 & 7.28 & 61.03 & 8.48 & 12.56 \\
\hline Sandy & $0-10$ & 40.68 & 0.77 & 7.28 & 59.32 & 10.48 & 14.56 \\
\hline Clay & $10-20$ & 56.21 & 0.73 & 9.28 & 43.79 & 14.48 & 10.56 \\
\hline \multirow[t]{5}{*}{ Loam } & $20-30$ & 41.94 & 0.85 & 5.28 & 58.07 & 12.48 & 16.56 \\
\hline & Mean & 4 & 0.71 & 13.31 & 55.70 & 11.65 & 19.25 \\
\hline & $\% \mathrm{CV}$ & 30.78 & 13.64 & 56.29 & 24.48 & 32.30 & 59.40 \\
\hline & & & & & & & \\
\hline & $0-10$ & 54.68 & 0.79 & 14.00 & 45.32 & 14.48 & 37.28 \\
\hline \multirow[t]{2}{*}{ Loam } & & 34. & 0.82 & 10.00 & 65.62 & 10.48 & 35.28 \\
\hline & $20-30$ & 39.58 & 0.82 & 10.00 & 60.42 & 10.48 & 35.28 \\
\hline Clay & & & 0.62 & & & 10.48 & 15.28 \\
\hline \multirow[t]{2}{*}{ Loam } & $10-20$ & 54.07 & 0.64 & 20.00 & 45.93 & 16.48 & 19.28 \\
\hline & $20-30$ & 43.50 & 0.57 & 24.00 & 56.50 & 18.48 & 13.28 \\
\hline Sandy & $0-10$ & 47.09 & 0.70 & 7.28 & 52.91 & 6.48 & 10.56 \\
\hline \multirow[t]{2}{*}{ Loam } & $10-20$ & 48.16 & 0.81 & 5.28 & 51.84 & 10.48 & 12.56 \\
\hline & $20-30$ & & 0.73 & 9.28 & & 12.48 & 12.56 \\
\hline Sancy & $0-10$ & 25.16 & 0.74 & 7.28 & 74.85 & 6.48 & 14.56 \\
\hline Clay & $10-20$ & 37.75 & 0.67 & 11.28 & 62.25 & 10.48 & 12.56 \\
\hline \multirow[t]{3}{*}{ Loam } & $20-30$ & 29.78 & 0.60 & 11.28 & 70.22 & 6.48 & 10.56 \\
\hline & Mean & 43.85 & 0.71 & 12.14 & 56.15 & 11.15 & 19.09 \\
\hline & $\% \mathrm{CV}$ & 25.30 & 12.63 & 45.38 & 19.76 & 34.50 & 54.66 \\
\hline \multicolumn{2}{|c|}{ Grand $\% \mathrm{CV}$} & 27.59 & 12.86 & 50.76 & 21.74 & 32.72 & 55.85 \\
\hline
\end{tabular}

CDI - clay dispersion index, DR - dispersion ratio,

ASC - aggregate silt and clay, CFI - Clay flocculation index,

WDC - water dispersible clay, WDSi - water dispersible silt 


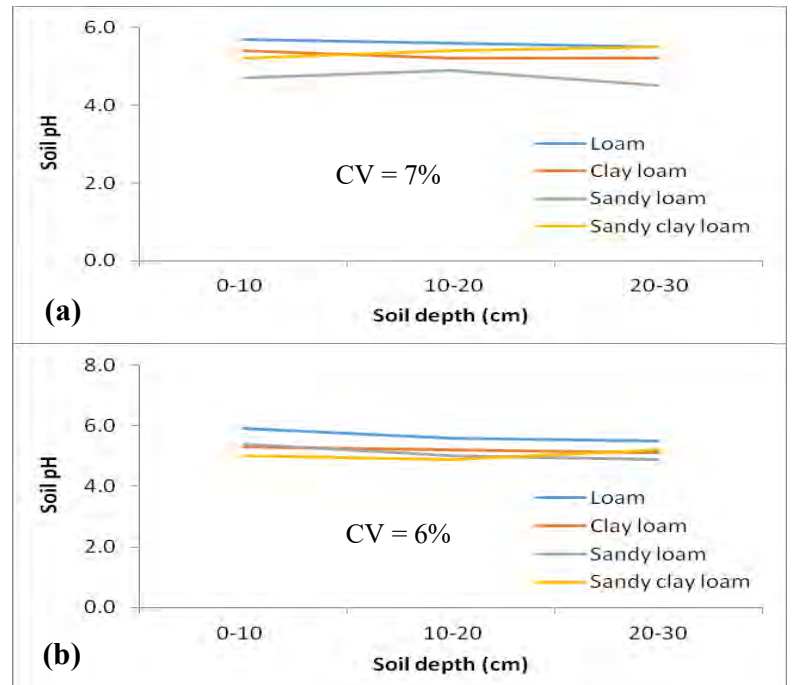

Figure 2: Soil $\mathrm{pH}$ of the different soils under cultivated (a) and uncultivated (b) land uses

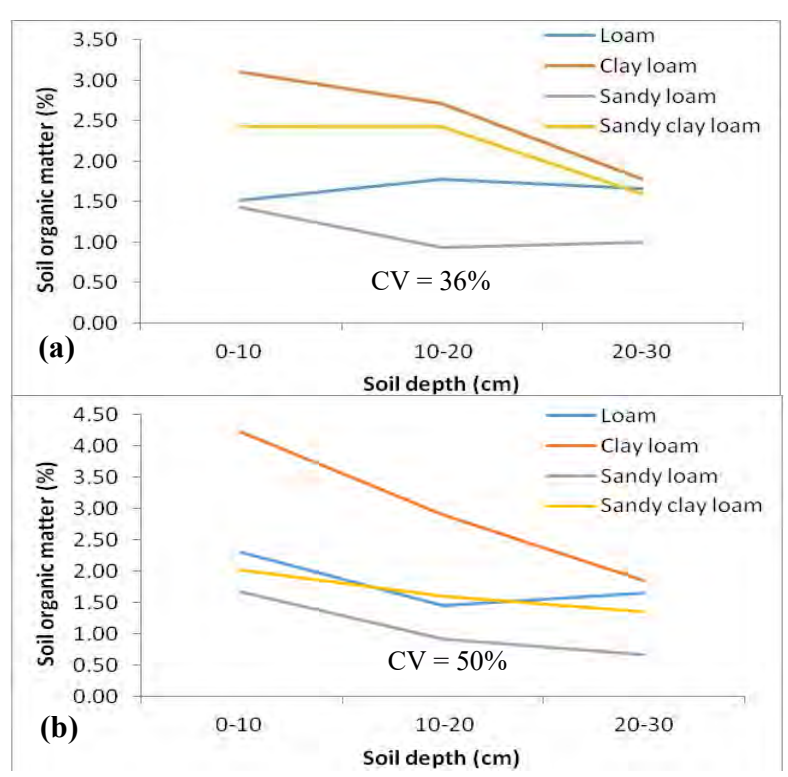

Figure 3: Soil organic matter content of the soils under cultivated (a) and uncultivated (b) land uses

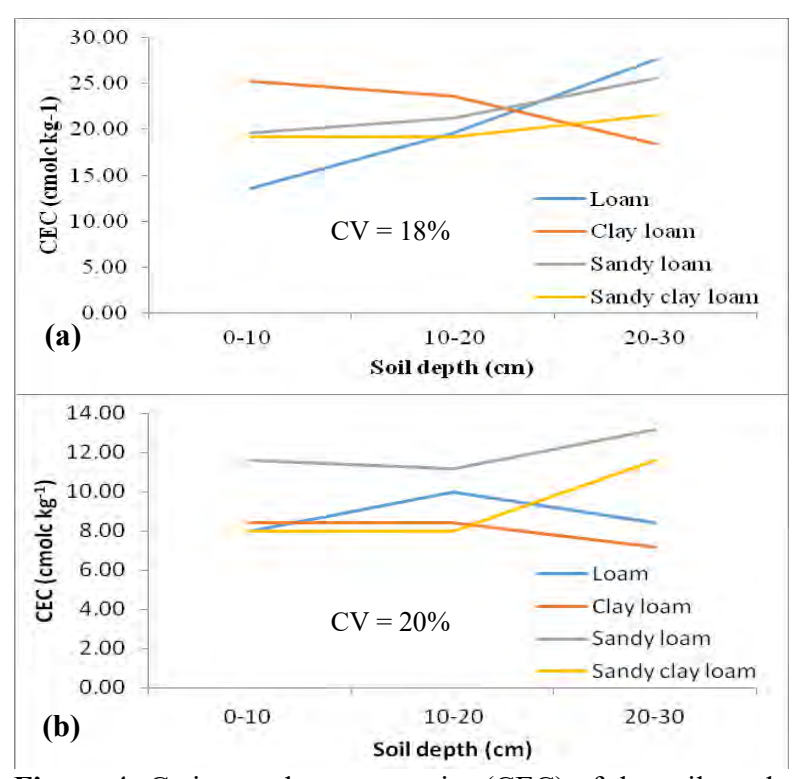

Figure 4: Cation exchange capacity (CEC) of the soils under cultivated (a) and uncultivated (b) land uses
Table 4: Percentages of water-stable aggregates of the soils under cultivated and uncultivated land uses

\begin{tabular}{|c|c|c|c|c|c|c|}
\hline \multirow{2}{*}{$\begin{array}{l}\text { Land use/ } \\
\text { soil texture }\end{array}$} & \multirow{2}{*}{$\begin{array}{l}\text { Depth } \\
\text { (cm) }\end{array}$} & \multicolumn{5}{|c|}{ Water-stable aggregates $(\mathrm{mm})$} \\
\hline & & $>2.00$ & $\begin{array}{l}1.00- \\
2.00\end{array}$ & $\begin{array}{l}0.50- \\
1.00\end{array}$ & $\begin{array}{c}0.25- \\
0.50 \\
\end{array}$ & $<0.25$ \\
\hline & & \multicolumn{5}{|c|}{ Cultivated } \\
\hline \multirow{3}{*}{ Loam } & $0-10$ & 46.15 & 13.47 & 10.34 & 10.22 & 19.82 \\
\hline & $10-20$ & 8.78 & 12.88 & 16.57 & 24.55 & 37.22 \\
\hline & $20-30$ & 7.19 & 27.68 & 23.50 & 17.32 & 24.33 \\
\hline Clay & $0-10$ & 65.69 & 13.22 & 6.47 & 5.18 & 9.44 \\
\hline \multirow[t]{2}{*}{ Loam } & $10-20$ & 52.70 & 19.86 & 11.21 & 5.56 & 10.67 \\
\hline & $20-30$ & 40.73 & 19.96 & 17.60 & 11.59 & 10.12 \\
\hline Sandy & $0-10$ & 19.67 & 30.52 & 21.83 & 11.41 & 16.57 \\
\hline \multirow{2}{*}{ Loam } & $10-20$ & 18.80 & 32.20 & 26.17 & 10.39 & 12.44 \\
\hline & $20-30$ & 18.21 & 29.28 & 29.06 & 10.15 & 13.30 \\
\hline Sandy & $0-10$ & 73.86 & 6.80 & 5.43 & 4.02 & 9.89 \\
\hline Clay & $10-20$ & 83.37 & 6.56 & 2.18 & 1.53 & 6.36 \\
\hline \multirow[t]{4}{*}{ Loam } & $20-30$ & 80.52 & 5.35 & 4.51 & 3.92 & 5.70 \\
\hline & Mean & 42.97 & 18.15 & 14.57 & 9.65 & 14.66 \\
\hline & $\% \mathrm{CV}$ & 65.86 & 54.40 & 62.87 & 66.70 & 60.87 \\
\hline & & \multicolumn{5}{|c|}{ Uncultivated } \\
\hline \multirow[t]{3}{*}{ Loam } & $0-10$ & 3.01 & 7.79 & 11.87 & 19.57 & 56.76 \\
\hline & $10-20$ & 2.84 & 22.36 & 21.50 & 11.50 & 41.80 \\
\hline & $20-30$ & 14.47 & 21.03 & 20.53 & 14.86 & 29.11 \\
\hline Clay & $0-10$ & 74.40 & 9.96 & 5.23 & 2.61 & 7.80 \\
\hline \multirow[t]{2}{*}{ Loam } & $10-20$ & 67.35 & 11.19 & 5.85 & 2.95 & 12.66 \\
\hline & $20-30$ & 56.47 & 16.32 & 12.78 & 5.35 & 9.08 \\
\hline Sandy & $0-10$ & 84.11 & 4.46 & 3.65 & 3.41 & 4.37 \\
\hline \multirow[t]{2}{*}{ Loam } & $10-20$ & 32.89 & 25.26 & 22.56 & 12.59 & 6.70 \\
\hline & $20-30$ & 31.15 & 37.58 & 17.21 & 7.67 & 6.39 \\
\hline Sandy & $0-10$ & 89.16 & 4.96 & 1.20 & 0.92 & 3.76 \\
\hline Clay & $10-20$ & 73.46 & 13.12 & 5.42 & 2.24 & 5.76 \\
\hline \multirow[t]{3}{*}{ Loam } & $20-30$ & 73.92 & 9.10 & 4.78 & 3.37 & 8.83 \\
\hline & Mean & 50.27 & 15.26 & 11.05 & 7.25 & 16.09 \\
\hline & $\% \mathrm{CV}$ & 63.19 & 63.98 & 69.94 & 82.62 & 106.78 \\
\hline
\end{tabular}

Total Soil Nitrogen Concentrations in Water-Stable Aggregates

The aggregate TSN range from $0.11-0.34 \%, 0.11-0.48 \%$, $0.06-0.28 \%$, and $0.08-0.39 \%$ in the L, CL, SL and SCL soils, respectively, across WSA fractions, soil depths and land uses (Figure 6). The CV amongst aggregate TSN fractions was between $29 \%$ and $38 \%$. With few exceptions, TSN concentrations across soil depths increased as the WSA fractions decrease, thus indicating more TSN in the micro-aggregates than macroaggregates in CL and SCL soils. In the CL soils, while TSN concentration across WSA fractions at $0-10 \mathrm{~cm}$ depth was more under the uncultivated $(0.20-0.36 \%)$ than cultivated $(0.14-0.34 \%)$ land use, the uncultivated land $(0.34-0.36 \%)$ had more TSN in $<0.50 \mathrm{~mm}$ than the cultivated land (0.22-0.34\%). Pooled over soil depths, the macro-aggregate-associated TSN was more in the uncultivated than cultivated soils of L and SL textures. Accordingly, more micro-aggregate-associated TSN under the cultivated than uncultivated land characterized the $\mathrm{L}$ and SL soils; the reverse was obtained in CL soil.

\section{C/N Ratio in Water-Stable Aggregates of the Soils}

The $\mathrm{C} / \mathrm{N}$ ratios of various WSA classes were generally low and varied greatly $(\mathrm{CV}>30 \%)$ amongst the soils and across soil depths in both land uses (Figure 7). Across land uses, the obtained $\mathrm{C} / \mathrm{N}$ values ranged from $1.77-10.50,1.69-9.14,1.79-10.67$ and $2.22-11.36$ in the L, CL, SL and SCL soils, respectively. While the trend in aggregate $\mathrm{C} / \mathrm{N}$ distribution with soil depth and land uses appears undefined amongst the soil textures, the $\mathrm{CL}$ soil mostly show maximum $\mathrm{C} / \mathrm{N}$ values at $0-10 \mathrm{~cm}$ depth across WSA fractions in both land uses. 


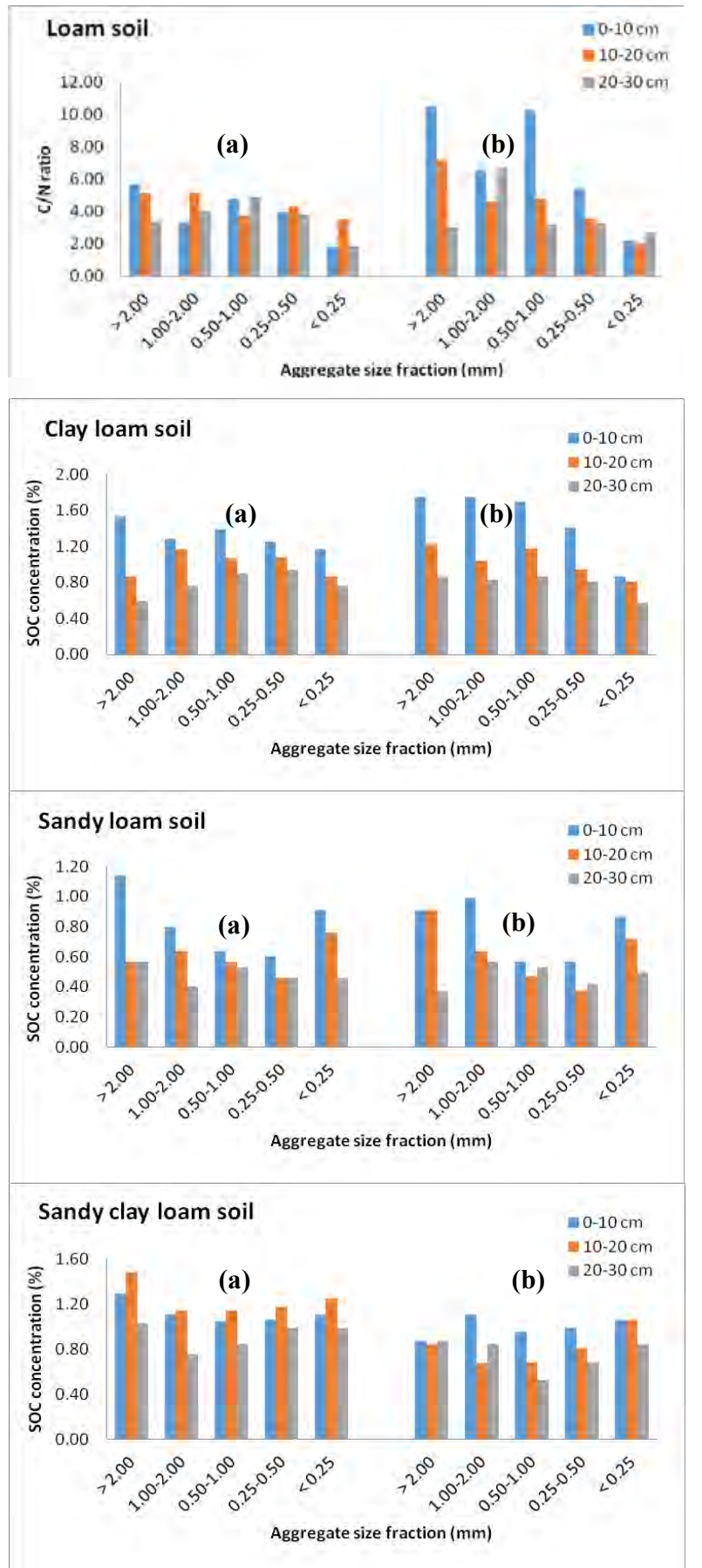

Figure 5: Aggregate soil organic carbon (SOC) concentrations under cultivated (a) and uncultivated (b) land uses

\section{DISCUSSION}

\section{Physicochemical Properties of the Soils}

The clay distribution within the soil depth indicated some form of eluviation and illuviation processes that had occurred within the soils. The more pronounced reduction in percent silt content with depth in the cultivated soils of Awgu and Okigwe could be related to deposition of silty materials through flooding or from mudflows or by river; and secondly, eluviation and illuviation processes move clay from the topsoil (hence increase in silt content) and deposit it in the subsoil (reduction of silt content). The comparatively high silt content in Awgu and Okigwe soils may be because the soils originated from the same parent material (Orajaka, 1975; Onyewuchi and Ugwu, 2017).
However, the high silt content in Awgu soil was mainly attributed to deposition of silt materials from a nearby river (Okebalama et al., 2017). The dominance of sand particles (> 66\%) across the soil depths and land uses is typical of the Sandstone parent material at Nsukka (Edeh et al., 2015). Possibly, these soils could be characterized as having better air and water permeability and hence enhanced drainage. Based on the content of the soil separates at $0-30 \mathrm{~cm}$ depth and for ease of evaluating the influence of soil texture on measured parameters, the studied soils were herein referred to as L, CL, SL and SCL, for Awgu, Okigwe, Nsukka I and II locations, respectively.

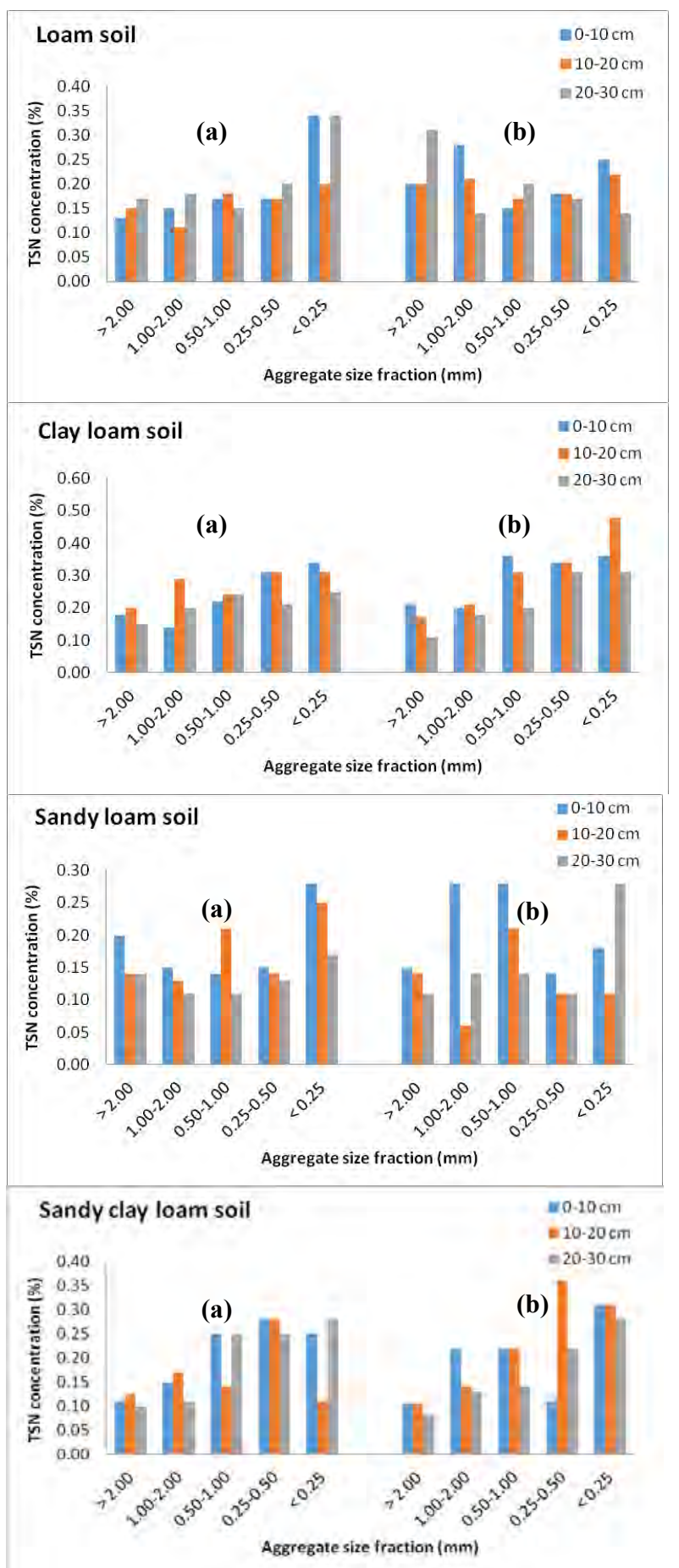

Figure 6: Aggregate total soil nitrogen (TSN) concentrations under cultivated (a) and uncultivated (b) land uses 


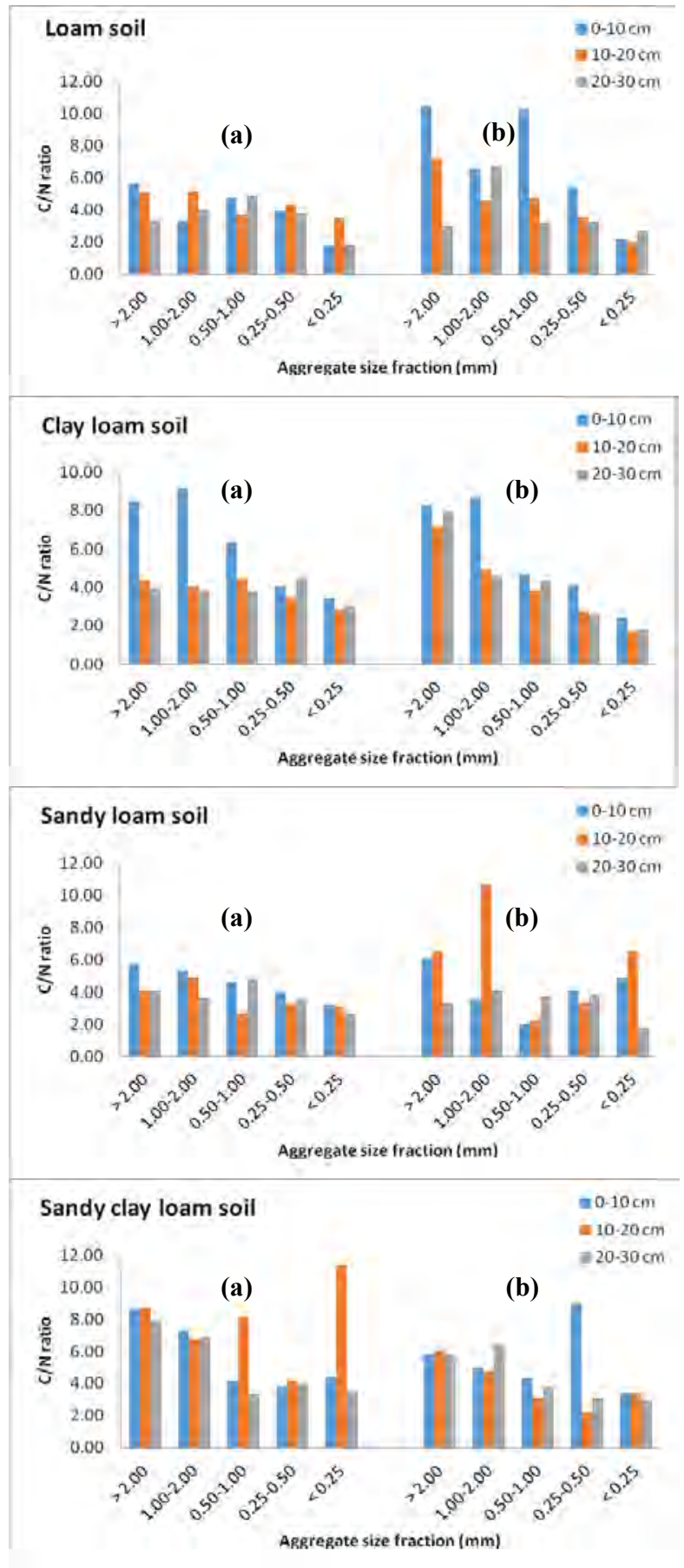

Figure 7: Aggregate $\mathrm{C} / \mathrm{N}$ ratio of the soils under cultivated (a) and uncultivated (b) land uses

All the determined micro-aggregate indices are important estimates of soil stability and dispersibility in water because of their significant in estimating the susceptibility of soil to water erosion (Igwe and Obalum, 2013; Zhu et al., 2018; Ahukaemere et al., 2021). High values of CFI and ASC imply better stability while high DR and CDI values indicate lower stability (Igwe et al., 1999; 2009). The low ASC and high DR values under both land uses suggest that the soils were structurally weak and instable in water. Similar observation in coarse textured soils as reported by Igwe and Udegbunam (2008) indicate that soils with high DR can easily erode. However, the moderate CDI and CFI show that the soils were moderately stable and less dispersive in water. Igwe et al. (1995) opined that CFI, amongst other aggregate indices, could better predict potential soil erodibility in some soils of southeastern Nigeria. Also, the low WDC and WDSi values indicating less dispersibility (Zhu et al., 2018) suggest that these soils may be less erodible despite the high rainfall regime of the study environment. Regarding the high variation in WDSi and WDC, the relatively high WDSi of the L soil resulted from its high silt content, while the relatively high WDC of the CL soil could be linked to high clay content as compared to the other soils. It is thus important to note the critical role of clay in aggregate stability of the soils. This could be ascribed to the inherent susceptibility of clay-rich soils since clay upon wetting swells, slakes or disperses.

The low $\mathrm{pH}$ of the soils was within the $\mathrm{pH}$ range of most acidic soils of the humid tropics (Igwe and Udegbunam, 2008; Agim et al., 2019). The pH of the soils was moderately acid, except the $\mathrm{pH}$ of the cultivated SL soil which falls within the strongly acidic range. The strongly acid $\mathrm{pH}$ could be linked to tillage (due to cultivation) which promoted leaching of base cations, leaving dominance of $\mathrm{H}^{+}$in the topsoil. This may have contributed to the low OM content of the SL soils in both land uses. In a similar manner, Igwe (2005) attributed low SOC contents of a strongly acid cultivated SL soil to severe leaching and inter-rill erosion due to high rainfall intensity.

The low SOM is common to the soils of the study area known for low fertility status (Anikwe, 2010; Obalum and Obi, 2010; Agim et al., 2019). The comparatively high SOM contents of the CL soils than the other soils under both land uses could be due to its high clay content, which enhanced soil aggregation via binding of SOM to soil minerals, and subsequent reduction in SOM oxidation and losses. The increased SOM content in the $0-10 \mathrm{~cm}$ depth was attributable to addition of organic matter from plant biomass and associated increased activity of soil microorganisms in decomposition and preservation of organic matter. More so, reduced erosion and surface runoff losses due to vegetation cover may contribute to increase in SOM at $0-10 \mathrm{~cm}$ depth. The organic materials were decomposed, redistributed and stored in successively layers within the soil profile, thus showing reduced concentration of SOM with soil depth as found in the uncultivated CL, SL and SCL soils. Such a decline in SOC concentration shows the effect of short-term fallow on the accumulation and segmental distribution of OC at intervals of $10 \mathrm{~cm}$ within the topsoil layer. The result buttresses the importance of segmental computation of topsoil SOC in soil science research (Kumar et al., 2013; Okebalama et al., 2017). The improvement in SOM content of the cultivated SCL soil could be linked to the effect of applied poultry manure. Addition of poultry droppings on SCL soil increased SOC following first time cultivation of a two-year bushfallow field (Okebalama et al., 2020).

The CEC of the soils were generally low, conceivably due to the inherent acid $\mathrm{pH}$ and low SOM content of the soils. Also, excessive precipitation contributes to considerable loss of basic cations through leaching and replacement of the exchange sites with acid cations (Igwe et al., 1999). The CEC of the soils 
are not different under each landuse, though the CEC of the cultivated soil is more than the uncultivated soils. This finding contradicts the report of reduced exchangeable cations concentrations following change in land use (Adesodun et al., 2007; Schweizer et al., 2017).

\section{Differences in Water-Stable Aggregates with Soil Textures and Land Uses}

The $\mathrm{L}$ soil under both land uses exhibited high rate of $>$ $2.00 \mathrm{~mm}$ aggregate instability in water, attributable to the high WDSi index of the soil. The CL and SCL soils had comparatively moderate to high stability of the $>$ $2.00 \mathrm{~mm}$ aggregates across soil depth and land uses. This observation could be due to the differences in clay content, SOM and parent material. Clay and oxides of $\mathrm{Fe}$ and $\mathrm{Al}$ are predominant aggregating agents in tropical soils (Igwe et al., 2013). Despite having originated from similar parent material as SCL, the cultivated SL soil exhibited high $>2.00 \mathrm{~mm}$ aggregates instability in water while the stability of the $>0.50 \mathrm{~mm}$ macro-aggregates in SCL soil was not influenced by cultivation processes. Adesodun et al. (2007) reported a decrease in $>0.50$ mm WSA of two SCL soils due to cultivation. In comparing WSA of cultivated and adjacent forested soils in Nigeria, Spaccini et al. (2001) found a significant reduction in $>1.00 \mathrm{~mm}$ macro-aggregate fractions of cultivated SCL and SL soils and concluded that cultivation had a lower impact on sandy than clayey soil.

Cultivation related increase in micro-aggregates of the cultivated SL soil which was created from the $>$ $2.00 \mathrm{~mm}$ macro-aggregates disintegration, could be explained by three possible reasons which are i) effect of reduced soil $\mathrm{pH}$ (strong acidity) on aggregate stability; ii) low SOM content; and iii) frequent soil disturbance (conventional tillage) within the three-year continuous land cultivation. Igwe and Udegbunam (2008) found that soil $\mathrm{pH}$, SOC, including clay and silt contents among others affects water-dispersible properties of Ultisols. Low soil $\mathrm{pH}$ affects microbial population and their capacity to produce organic compounds that promotes soil aggregates stabilization (Castro Filho et al., 2002). Six et al. (1999) recognized the importance of SOC in macro-aggregate formation because it provides energy for microbes that are responsible for soil aggregation. Blanco-Canqui and Benjamin (2013) also reported decrease in aggregate stability with SOC decrease. Puget et al. (2000) found that macro-aggregates are more sensitive than microaggregates in responding to changes in land use and adverse cultivation processes. Accordingly, the maximal $>2.00 \mathrm{~mm}$ aggregates reduction at $0-30 \mathrm{~cm}$ depth in the cultivated SL than cultivated CL soils suggests that the formation of stable micro-aggregates within macroaggregates was impeded due to loss of intra-particulate $\mathrm{OM}$ during aggregate turn over. Nonetheless, the study results indicate that cultivating SL and CL soils reduced the $>2.00 \mathrm{~mm}$ WSA to smaller fractions.

The reduced stability of the $>2.00 \mathrm{~mm}$ WSA with increased soil depth followed similar trend with the SOM concentration but trailed inversely with the percentage clay content of the CL and SL soils. This implies that the formation and stability of $>2.00 \mathrm{~mm}$ aggregates was mainly controlled by SOM content, thus confirming that macro-aggregation depends on SOM (Boix-Fayos et al., 2001). In view of that, though high clay and SOM contents marked CL and SCL soils, they had comparatively low micro-aggregates $(<0.50 \mathrm{~mm})$ compared to that in the $\mathrm{L}$ and SL soils. It thus suggests that clay particles and SOM may be contributing to macro-aggregation $(>0.50 \mathrm{~mm})$ in $\mathrm{CL}$ and SCL soils.

\section{Soil Organic Carbon Concentration in Water-Stable Aggregates}

The low aggregate SOC concentrations of the soils could be linked to decreased plant biomass inputs, increased SOM decomposition because of high temperature regime and increased soil erosion/runoff and leaching losses due to the high rainfall that prevails in the study environment (Igwe, 2005; Igwe et al., 2009; 2013). The decline in aggregate SOC concentration with increased soil depth indicates the positive effect of bush-fallow and the capacity of the uncultivated L and CL soils to promote OC storage in successive soil layers. In contrast to CL soils, this pattern was not maintained in the cultivated $\mathrm{L}$ soil probably because of the nature of the soil which predisposes it to structural degradation and subsequent SOC loss following cultivation processes. Land use type affects the amount and quality of litter input, litter decomposition rates and the processes of $\mathrm{OM}$ stabilization in soils (Shepherd et al., 2001). The maximal aggregate $\mathrm{SOC}$ at $0-10 \mathrm{~cm}$ depth which cut across the soil textural types; except in the cultivated L and SCL soils, connotes high OC accumulation and preservation due to enriched influx of organic material and slow breakdown and mineralization. The relatively high aggregate $\mathrm{SOC}$ at $10-20 \mathrm{~cm}$ compared to $0-10 \mathrm{~cm}$ in the cultivated SCL soil suggests cultivation related SOC loss, exacerbated by severe erosion and runoff due to the hilly terrain of the site.

The preferential maximal accumulation of SOC in macro-aggregates in all the soils under both land uses, except in the cultivated $\mathrm{L}$ soil is similar to the reportedly higher SOC in large macro-aggregates $(4.76-2.0 \mathrm{~mm})$ under uncultivated soil (Adesodun et al., 2007). High accumulation of SOC in macro- than micro- aggregates could be explained by the aggregate $\mathrm{C} / \mathrm{N}$ ratio which decreased with decrease in WSA fractions. This indicates that microbial alteration of SOM was more associated with the micro-aggregates than the macroaggregates. The impact of land use change on SOC storage of the soils at $0-30 \mathrm{~cm}$ depth was more on the macro- than the micro- aggregate. According to Puget et al. (2005), macro-aggregate associated SOC is mostly labile with faster turnover rates as compared to micro-aggregate associated SOC.

The influence of cultivation in reducing macroaggregate associated SOC concentration in the L, CL and SL soils indicate the susceptibility of these soils to SOC losses upon change in landuse. Notably, the macro-aggregate associated SOC loss at 0-30 cm depth in the $>2.00,1.00-2.00$, and $0.50-1.00 \mathrm{~mm}$ WSA fractions amounted to $112 \%, 108 \%$ and $35 \%$, respectively, in the $\mathrm{L}$ soil; and $28 \%, 12 \%$ and $12 \%$, respectively, in the CL soil. With $20 \%$ SOC loss in the $1.00-2.00 \mathrm{~mm}$ fractions of the SL soil, the susceptibility 
of the soils to macro-aggregate associated SOC loss was more in the $\mathrm{L}>\mathrm{CL}>\mathrm{SL}$ textured soils. This implies higher SOC loss in silt-, and clay- than in sanddominated soil. On the contrary, Spaccini et al. (2001) found that decreased macro-aggregate associated SOC as influenced by soil texture was generally greater in sandy than clayey soils. Feller and Beare (1997) reported that soil aggregation, texture and mineralogy control SOC storage in macro-aggregates while Kumar et al. (2013) stated that the residence time of aggregate associated SOC determines its storage and stabilization in soils. In this study, the cultivation-related reduction in macro-aggregate associated SOC may have resulted from soil disturbance which disaggregated the aggregates and increased oxidation of exposed SOM by microbes, thus exacerbating $\mathrm{C}$ loss through erosion/runoff and emission to the atmosphere. Research findings in confirmation to this abound in the literature (Follett, 2001; Spaccini et al., 2001; Wright and Hons, 2005).

Despite the reduced stability of the $>2.00 \mathrm{~mm}$ aggregates in cultivated SL soil, the influence of cultivation on SOC loss was limited to the 1.00-2.00 $\mathrm{mm}$ fractions. Even so, the somewhat comparable SOC concentrations of the other aggregate fractions under both land uses suggest that the soil is rather not inclined to SOC losses upon land use change. This could be ascribed to the positive effect of the three-year fertilizer application which might have promoted aggregate SOC storage such that the frequent soil disruption due to conventional tillage did not inhibit the formation of stable micro-aggregates within macro-aggregates of $>$ 2.00 and $0.50-1.00 \mathrm{~mm}$ (Six et al., 1998). Similarly, the improved aggregate SOC which cuts across almost all the WSA fractions, soil depths and land uses of SCL soil is attributable to the positive effect of poultry manure input used in crop cultivation. This indicates the capability of SCL to conserve SOC in cultivated land.

The non-reduction in micro-aggregate associated SOC of all the cultivated soils supports that SOC was more stabilized in micro-aggregates (Bayer et al., 2000). Such effectual SOC preservation implies that the cultivation processes had no negative effect on microaggregate associated SOC. The short-term bush-fallow seems to have improved SOC stabilization in microaggregate fractions, as this appears to be independent of the soils' textural types. Micro-aggregates retain SOC in a way that is comparatively less susceptible to physical disturbance (Puget et al., 2000). The association of SOC to silt-and clay-size fractions maintains a strong link to mineral particles, thereby forming OM-mineral complexes (Khanday et al., 2017). Moreover, the confinement of OC in the core of soil micro-aggregates with long mean residence time makes it inaccessible to microbial decomposition (Laird, 2001). This essential mechanism explains the involvement of the soil microaggregates in both $\mathrm{C}$ and $\mathrm{N}$ sequestration.

\section{Total Soil Nitrogen Concentrations in Water-Stable Aggregates}

The TSN concentrations in various WSA fractions of the soils, across soil depth and land uses were generally low. The low aggregate TSN concentration of the soils could be linked to low $\mathrm{pH}$ of the soils which probably reduced microbial activities and retarded nitrification of OM (Jiang and Bakken, 1999). Perhaps, replacing bushfallow with improved-fallow which incorporates planting leguminous crops on fallowed agricultural abandoned fields could increase the $\mathrm{N}$ content and consequently, boost $\mathrm{C}$ build up in the soils. Knops and Tilman (2000) observed that the rate of $\mathrm{C}$ accumulation in agricultural abandoned fields was controlled by the rate of $\mathrm{N}$ accumulation, which in turn depends on atmospheric $\mathrm{N}$ deposition and symbiotic $\mathrm{N}$ fixation by legumes. Notably, the aggregate-associated TSN was relatively high in the CL soil compared to the L and SL soils. This could be explained by the differences in SOM mineralization in the micro-aggregates of these soils. The higher microthan macro-aggregate-associated TSN in the CL and SCL soils under both land uses is similar to Agim et al.'s (2019) observation in SCL soil, but differs with the findings of Adesodun et al. (2007) who reported greater TSN in $>2.0 \mathrm{~mm}$ and $<0.25 \mathrm{~mm}$ aggregates under uncultivated and cultivated SCL soils, respectively.

Aggregate TSN distribution with soil depth was not consistently similar amongst the study soils. The maximal accumulation of aggregate TSN of uncultivated CL soils at $0-10 \mathrm{~cm}$ depth suppose that the bush-fallow period probably enhanced $\mathrm{N}$ stabilization in the various WSA fractions. Ironically, the influence of cultivation on CL soil resulted to between 6 and $63 \%$ aggregate TSN losses, with greater loss by the macrothan the micro aggregates. At $0-30 \mathrm{~cm}$ depth, the improved TSN concentrations in $>1.00 \mathrm{~mm}$ WSA under cultivated landuse was possible due to $\mathrm{N}$ addition from the decomposed residue biomass used as mulch. Nevertheless, cultivation-related reduction in microaggregate associated TSN concentrations amounted to $19-27 \%$ in the $<0.50 \mathrm{~mm}$ by the CL soil and to about $41 \%$ in the $<0.25 \mathrm{~mm}$ WSA by the SCL soil. Conversely, the improved micro-aggregates associated TSN as recorded in the cultivated L and SL soils suggest that these soils are capable of promoting $\mathrm{N}$ storage and preservation in micro-aggregates. Hence, the impact of short-term bush-fallow on microaggregate associated TSN conservation in cultivated systems is dependent on soil textures.

Cultivation induced reduction in macro-aggregate associated TSN affected all the soil textural types at 0-30 $\mathrm{cm}$ depth. Consequently, 24\% TSN loss was recorded in the $0.50-1.00 \mathrm{~mm}$ WSA fraction (CL), whereas $14 \%$ loss of TSN was obtained in the 1.00-2.00 mm WSA fractions (SCL). Greater macro-aggregate associated TSN losses as obtained in the L textured soil amounted to $58 \%, 43 \%$ and $4 \%$ in the $>2.00,1.00-2.00$ and 0.50 $100 \mathrm{~mm}$ WSA fractions, respectively. However, in the SL textured soil, losses were $23 \%$ and $37 \%$ in the 1.00 $2.00 \mathrm{~mm}$ and $0.50-1.00 \mathrm{~mm} \mathrm{WSA}$, respectively. It therefore indicates that $\mathrm{L}$ and $\mathrm{SL}$ soils were most susceptible to cultivation related macro-aggregate SOC loss as compared to CL and SCL soils. Over all, the susceptibility of the soils to macro-aggregate associated TSN loss was greater in the $\mathrm{L}>\mathrm{SL}>\mathrm{CL}>\mathrm{SCL}$ soils. It thus implies that the 4 to 5 years bush fallow period enhanced stabilization of macro-aggregate associated TSN in the CL and SCL more than in L and SL soils. 


\section{CONCLUSIONS}

Soil aggregate stability and the distributions of SOC and TSN in WSA of the studied soil textures across soil depths and under both land uses are heterogeneous. The stability of the $>2.00 \mathrm{~mm}$ aggregates at $0-30 \mathrm{~cm}$ depth under both land uses is comparatively high in CL and SCL and low in L and SL soils. All the soil textural types are capable of storing more SOC in macro- than micro- aggregate at $0-30 \mathrm{~cm}$ depth under both land uses. However, cultivation related SOC reduction mostly affects the macro- but not the micro- aggregates in these soils. Accordingly, the macro-aggregates associated SOC losses at 0-30 $\mathrm{cm}$ depth was greater with $\mathrm{L}>\mathrm{CL}>$ SL soils. Aggregate TSN of the uncultivated CL soil is subject to losses due to cultivation influence, with greater loss in the macro- than the micro- aggregates. Across soil depths, high micro- than macro- aggregate associated TSN characterized L, CL, SL and SCL of the cultivated soils. However, only the cultivated L and SL soils are capable of micro-aggregates associated TSN conservation and improvement. At 0-30 cm depth, reduction in macro-aggregate associated TSN concentrations was more pronounced in the $>0.50 \mathrm{~mm}$ (L), 0.50-1.00 mm (CL), 0.50-2.00 mm (SL), and 1.00$2.00 \mathrm{~mm}$ (SCL) WSA fractions with higher susceptibility by the $\mathrm{L}>\mathrm{SL}>\mathrm{CL}>\mathrm{SCL}$ soils. Therefore, cultivation induced macro-aggregate associated SOC and TSN losses are greater in silt- than in clay- and sand- dominated textured soils.

\section{ACKNOWLEDGMENTS}

The first author (CBO) appreciates the contribution of 'Alexander von Humboldt Foundation' via the 'Humboldt Research Fellowship for Postdoctoral Researchers' programme which facilitated assembling of the manuscript.

\section{REFERENCES}

Adesodun J.K., Adeyemi E.F. and Oyegoke C.O. (2007). Distribution of nutrient elements within water-stable aggregates of two tropical agro-ecological soils under different land uses. Soil Tillage Res., 92 (1-2), 190-197

Agim L.C., Ahukaemere C.M., Onwudike S.U., et al. (2019). Distribution of selected soil nutrients in aggregate sizes of soils under different geologic formations in southeast Nigeria. Bulgarian J. Soil Sci., 4 (2), 116-131

Ahukaemere C.M., Onweremadu E.U. and Akamigbo F.O.R. (2021). Erodibility of soils of varying land utilization types and lithologic materials in central southeastern Nigeria. Agro-Science, 20 (3), 104-109

Anikwe M.A. (2010). Carbon storage in soils of Southeastern Nigeria under different management practices. Carbon Bal. Manage., 5 (1), 1-7

Ayoola O.T. and Adeniyan O.N. (2006). Influence of poultry manure and NPK fertilizer on yield and yield components of crops under different cropping systems in south west Nigeria. Afr. J. Biotechnol., 5 (15), 1386-1392

Bayer C., Mielniczuk J., Amado T.J., Martin-Neto L. and Fernandes S.V. (2000). Organic matter storage in a sandy clay loam Acrisol affected by tillage and cropping systems in southern Brazil. Soil Tillage Res., 54 (1-2), 101-109

Blanco-Canqui H. and Benjamin J. G. (2013). Impacts of soil organic carbon on soil physical behavior. Quantifying \& Modeling Soil Structure Dynamics, 3, 11-40
Boix-Fayos C., Calvo-Cases A., Imeson A.C. and SorianoSoto M.D. (2001). Influence of soil properties on the aggregation of some Mediterranean soils and the use of aggregate size and stability as land degradation indicators. Catena, 44 (1), 47-67

Bremner J.M. and Mulvaney C.S. (1982). Nitrogen-total. In: Page A.L., Miller R.H. and Keeney D.R. (eds.), Methods of Soil Analysis, Part 2 (pp. 595-624). Madison WI: American Society of Agronomy

Bronick C.J. and Lal R. (2005). Soil structure and management: a review. Geoderma, 124 (1-2), 3-22

Campbell C.A. and Souster W. (1982). Loss of organic matter and potentially mineralizable nitrogen from Saskatchewan soils due to cropping. Canadian J. Soil Sci., 62 (4), 651-656

Castro Filho C.D., Lourenço A., Guimarães M.D.F. and Fonseca I.C.B. (2002). Aggregate stability under different soil management systems in a red latosol in the state of Parana, Brazil. Soil Tillage Res., 65 (1), 45-51

Climate-Data (2021). Climate: Enugu. Accessed 17 Sep. 2021 from https://en.climate-data.org/africa/nigeria/enugu-350/

Edeh I.G., Igwe C.A. and Ezeaku P.I. (2015). Effects of rumen digesta on the physico-chemical properties of soils in Nsukka, Southeastern Nigeria. Afr. J. Biotechnol., 14 (22), 1873-1879

Elliott E.T. (1986). Aggregate structure and carbon, nitrogen, and phosphorous in native and cultivated soils. Soil Sci. Soc. Am. J., 50, 627-633

Feller C. and Beare M.H. (1997). Physical control of soil organic matter dynamics in the tropics. Geoderma, 79 (1-4), 69-116

Follett R.F. (2001). Soil management concepts and carbon sequestration in cropland soils. Soil Tillage Res, 61 (1-2), 77-92

Gee G.W. and Bauder J.W. (1986). Particle-size analysis. In: Klute A. (ed.) Methods of Soil Analysis, Part 1 (pp. 91-100). Madison WI: American Society of Agronomy

Igwe C.A. (2005). Erodibility in relation to water-dispersible clay for some soils of eastern Nigeria. Land Degrad. Dev., 16 (1), 87-96

Igwe C.A. and Udegbunam O.N. (2008). Soil properties influencing water-dispersible clay and silt in an Ultisol in southern Nigeria. Int. Agrophy, 22 (4), 319-325

Igwe C.A. Obalum S.E. (2013). Microaggregate stability of tropical soils and its roles on soil erosion hazard prediction, Advances in Agrophysical Research (Chap. 8), Stanisław Grundas (ed.), ISBN: 978-953-51-1184-9, InTech, DOI: 10.5772/52473. Available from: http://www.intechopen. $\mathrm{com} /$ books/advances-in-agrophysical-research/microaggre gate-stability-of-tropical-soils-and-its-roles-on-soil-erosion -hazard-prediction

Igwe C.A., Akamigbo F.O.R. and Mbagwu J.S.C. (1999). Chemical and mineralogical properties of soils in southeastern Nigeria in relation to aggregate stability. Geoderma, 92 (1-2), 111-123

Igwe C.A., Zarei M. and Stahr K. (2009). Colloidal stability in some tropical soils of southeastern Nigeria as affected by iron and aluminium oxides. Catena, 77 (3), 232-237

Igwe C.A., Zarei M. and Stahr K. (2013). Stability of aggregates of some weathered soils in south-eastern Nigeria in relation to their geochemical properties. $J$. Earth Sys. Sci., 122 (5), 1283-1294

Jiang Q.Q. and Bakken L.R. (1999). Comparison of Nitrosospira strains isolated from terrestrial environments. FEMS Microbiol. Ecol., 30 (2), 171-186

Jungerius P.D. (1964). The soils. In: Soil Survey Memoir No. 1. The Anambra - Do River area (pp. 1-22). Government Printers, Enugu 
Knops J.M. and Tilman D. (2000). Dynamics of soil nitrogen and carbon accumulation for 61 years after agricultural abandonment. Ecology, 81 (1), 88-98

Khanday M.U., Wani J.A., Ram D. and Jan R. (2017). Quantifying the stock of soil carbon sequestration in different land uses: An overview. Int. J. Curr. Microbiol. Appl. Sci., 6 (4), 382-392

Kumar R., Rawat K.S., Singh J., Singh A. and Rai A. (2013). Soil aggregation dynamics and carbon sequestration. $J$. Appl. Nat. Sci., 5 (1), 250-267

Laird D. (2001). Nature of clay-humic complexes in an agricultural soil. II. Scanning electron microscopy analysis. Soil Sci. Soc. Am. J. 65 (5), 1419-1425

Lal R. (1991). Soil structure and sustainability. J. Sustainable Agric., 1 (4), 67-92

Lal R. (2019). Accelerated soil erosion as a source of atmospheric $\mathrm{CO}_{2}$. Soil Tillage Res., 188, 35-40

Liu M., Han G. and Zhang Q. (2019). Effects of soil aggregate stability on soil organic carbon and nitrogen under land use change in an erodible region in Southwest China. Int. J. Environ. Res. Public Health, 16 (20), 3809

Mtali-Chafadza L., Manzungu E. and Mugabe P.H. (2020). Soil fertility status of abandoned fields in smallholder agriculture in South Central Zimbabwe. Phy. Chem Earth, Parts $A / B / C, 118,102896$

Nelson D.W. and Sommers L. (1982). Total carbon, organic carbon, and organic matter. Methods of Soil Analysis, Part 2: Chemical and Microbiological Properties, 9 (pp. 539-579). Madison WI: American Society of Agronomy

Nhantumbo A.B., Ledin S. and Du Preez C.C. (2009). Organic matter recovery in sandy soils under bush fallow in southern Mozambique. Nutr. Cycl. Agroecosys, 83 (2), 153-161

Obalum S.E. and Obi M.E. (2010). Physical properties of a sandy loam Ultisol as affected by tillage-mulch management practices and cropping systems. Soil Tillage Res., 108 (1-2), 30-36

Ogban P.I., Ukpong U.K. and Essien I.G. (2004). Interrelationship between bush fallow and the physical and chemical properties of "acid" sands in Southeastern Nigeria. Nig. J. Soil Environ. Res., 5, 32-43

Okebalama C.B., Igwe C.A. and Okolo C.C. (2017). Soil organic carbon levels in soils of contrasting land uses in southeastern Nigeria. Trop. Subtrop. Agroecosys., 20, 493-504

Okebalama C.B., Ogunezi K.C., Agbo I.C. and Asogwa K.C. (2020). Influence of soil amendment with poultry droppings on the soil properties and productivity of cucumbers (Cucumis sativus L.) on a degraded Ultisol in Nsukka Area, Southeast Nigeria. Nig. J. Soil Sci, 30 (2), 85-94

Onweremadu E.U., Onyia V.N. and Anikwe M.A.N. (2007). Carbon and nitrogen distribution in water-stable aggregates under two tillage techniques in Fluvisols of Owerri area, southeastern Nigeria. Soil Tillage Res., 97 (2), 195-206

Onyewuchi R.A. and Ugwu S.A. (2017). Litho-structural mapping of Udi and Okigwe area, Southeastern Nigeria using Landsat 5 Enhanced Thematic Mapper $\left(\mathrm{ETM}^{+}\right)$ Imagery. J. Sci. Eng. Res., 4 (9), 31-43

Orajaka S.O. (1975). Geology. In: Ofomata G.E.K. (ed.) Nigeria in Maps, Eastern States (pp. 5-7). Ethiopes Publishers, Benin City, Nigeria

Puget P., Chenu C. and Balesdent J. (2000). Dynamics of soil organic matter associated with particle-size fractions of water-stable aggregates. Europ. J. Soil Sci., 51 (4), 595-605
Puget P., Lal R., Izaurralde C., Post M. and Owens L. (2005). Stock and distribution of total and corn-derived soil organic carbon in aggregate and primary particle fractions for different land use and soil management practices. Soil Sci., 170 (4), 256-279

Rahman M.M. (2010). Carbon sequestration options in soils under different crops and their management practices. The Agriculturists, 8 (1), 90-101

Rahman M.M. (2013). Nutrient-use and carbon-sequestration efficiencies in soils from different organic wastes in rice and tomato cultivation. Comm. Soil Sci. Plant Anal., 44 (9), 1457-1471

Ramakrishnan P.S. (1984). The science behind rotational bush fallow agriculture system (jhum). Proceedings: Plant Sciences, 93 (3), 379-400

Saggar S., Yeates G.W. and Shepherd T.G. (2001). Cultivation effects on soil biological properties, microfauna and organic matter dynamics in Eutric Gleysol and Gleyic Luvisol soils in New Zealand. Soil Tillage Res., 58 (1-2), 55-68

Salako F.K., Babalola O., Hauser S. and Kang B.T. (1999). Soil macroaggregate stability under different fallow management systems and cropping intensities in southwestern Nigeria. Geoderma, 91 (1-2), 103-123

Schlecht E. and Buerkert A. (2004). Organic inputs and farmers' management strategies in millet fields of western Niger. Geoderma, 121 (3-4), 271-289

Schweizer S.A., Fischer H., Häring V. and Stahr K. (2017). Soil structure breakdown following land use change from forest to maize in Northwest Vietnam. Soil Tillage Res., 166, 10-17

Shepherd T.G., Saggar S., Newman R.H., Ross C.W. and Dando J.L. (2001). Tillage-induced changes to soil structure and organic carbon fractions in New Zealand soils. Soil Res., 39 (3), 465-489

Shrestha B.M., Singh B.R., Sitaula B.K., Lal R. and Bajracharya R.M. (2007). Soil aggregate-and particleassociated organic carbon under different land uses in Nepal. Soil Sci. Soc. Am. J., 71 (4), 1194-1203

Six J., Elliott E.T., Paustian K. and Doran J.W. (1998). Aggregation and soil organic matter accumulation in cultivated and native grassland soils. Soil Sci. Soc. Am. J., 62 (5), 1367-77

Six J., Elliott E.T. and Paustian K. (1999). Aggregate and soil organic matter dynamics under conventional and no-tillage systems. Soil Sci. Soc. Am. J., 63 (5), 1350-1358

Spaccini R., Zena A., Igwe C.A., Mbagwu J.S.C. and Piccolo A. (2001). Carbohydrates in water-stable aggregates and particle size fractions of forested and cultivated soils in two contrasting tropical ecosystems. Biogeochem., 53 (1), 1-22

Thomas G.W. (1982). Exchangeable cations. Methods of Soil Analysis, Part 2: Chemical and Microbiological Properties 9 (pp. 159-165). Madison, WI: American Society of Agronomy

Tisdall J.M. and Oades J.M. (1982). Organic matter and waterstable aggregates in soils. J. Soil Science, 33 (2), 141-163

Wright A.L. and Hons F.M. (2005). Soil carbon and nitrogen storage in aggregates from different tillage and crop regimes. Soil Sci. Soc. Am. J., 69 (1), 141-147

Zhu F., Cheng Q., Xue S., et al. (2018). Influence of natural regeneration on fractal features of residue microaggregates in bauxite residue disposal areas. Land Degrad. Dev., 29 (1), 138-149 